\title{
PETROFYZIKÁLNÍ CHARAKTERISTIKA SPRAŠE A FOSILNÍ PŮDY V HLINÍKU U LITOVLE
}

\author{
Petrophysical characterization of loess-paleosol sequence from the brickyard in Litovel
}

\author{
Daniel Šimíček $\square$, Vendula Krulová \\ Katedra geologie PřF UP, 17. listopadu 1192/12, 77146 Olomouc
}

Key words: Upper Moravian Basin, loess, petrophysics, geochemistry, Quaternary

\begin{abstract}
Loess-paleosol sequences are an important source of terrestrial paleoclimatic proxy-data. Quaternary loess and loess loam cover the most of surface of the Upper Moravian Basin. Samples from loess-paleosol sequence in vicinity of Litovel town were studied using magnetic susceptibility, spectrophotometry and laser granulometry. Obtained petrophysical data were compared with detailed lithological description of section and geochemical characteristics determined by ED-XRF method. The results contribute to interpretation of paleoclimate in the Upper Moravian Basin during the last glacial.

Section with total thickness of about $5 \mathrm{~m}$ is formed by loess in its upper part. This layer covers several soil horizons. It is most probably youngest loess deposit formed during the last glacial maximum. Petrophysical and geochemical data and comparison with nearby sites indicate relatively humid cold tundra conditions with bush-steppe vegetation during deposition of loess. Lithological features, position below youngest loess deposit and petrophysical and geochemical data allow interpretation of soil horizons as PK I. Low values of magnetic susceptibility indicate formation of soil in arctic interstadial conditions with higher humidity compared to interstadial average. Values of magnetic susceptibility of PK I are equal or even lower than in overlaying loess which doesn't correspond with usual behaviour of magnetic susceptibility in loess-paleosol sequences in the Czech Republic. It could be explained by formation of soil horizons in cold interstadial climate (low production of oxi/hydroxide of Fe) supplemented by increased humidity and hence, intensive illimerization process (clay migration and Fe-minerals depletion).
\end{abstract}

Úvod

Spraš lze charakterizovat jako světle žlutohnědý nezvrstvený dokonale vytř́iděný sediment s průměrnou velikostí zrna 0,02-0,05 mm (Smalley, Vita-Finzi 1968). Spraše jsou tvořeny především křemenem a dále živci a slídami. Charakteristický je vyšší obsah $\mathrm{CaCO}_{3}$, který se často soustředuje do konkrecí, tzv. cicvárů (Pye 1995). Vzniká akumulací prachu navátého větrem, který záhy podléhá souboru pedogenních procesů, označovaných jako loesifikace (zesprašnění) a které vedou k rychlému zpevnění eolického materiálu i změně původního minerálního složení (Zeman, Demek 1984; Cílek 2001). Sprašo-půdní komplexy, čili několik sprašových pokryvů nad sebou, oddělených fosilními půdami, představují neocenitelný zdroj informací o změnách kvartérního klimatu v kontinentálním prostředí (Kukla, Cílek 1996). V obdobích př́iznivých pro pedogenezi jsou spraše vhodným půdotvorným substrátem. $Z$ charakteru spraší a půd je možné odhadnout teplotní, srážkové i jiné vlastnosti klimatu, jako např́ílad informace o směru a síle větru (Smith et al. 2002). Sprašo-půdním komplexům na Olomoucku nebyla dosud věnována velká pozornost. Tato studie srovnává petrofyzikální data (magnetická susceptibilita, spektrální fotometrie, laserová granulometrie) s údaji o celkovém chemismu (EDXRF) spraší a fosilní půdy na lokalitě v blízkosti města Litovle. Interpretace získaných proxy-dat přináší informace o klimatických podmínkách v Hornomoravském úvalu a stratigrafii fosilní půdy.

$\triangle$ daniel.simicek@upol.cz

DOI: https://doi.org/10.5817/GVMS2018-1-2-58

\section{Lokalizace a geologická charakteristika území}

Studovaná lokalita se nachází v s. části Hornomoravského úvalu, poblíž styku Prostějovské pahorkatiny se Středomoravskou nivou (Demek et al. 2006). Výzkum byl proveden v bývalém hliníku (obr. 1), jižně od centra Litovle (GPS souřadnice: N 4940`42.9“E 17²435.4“). Ve východní, cca $6 \mathrm{~m}$ vysoké stěně, byly začištěny čtyři dílčí rýhy (obr. 2), které byly následně sloučeny do $480 \mathrm{~cm}$ mocného integrovaného profilu (obr. 3). Profil se kryje s místem dřivějšího odběru vzorku na OSL datování. Podle něj je stáří svrchního sprašového pokryvu 21,45 $\pm 2,02$ ka BP (Bábek et al. 2018).

Předkvarterní podloží Hornomoravského úvalu zahrnuje předdevonské krystalinikum, devonské platformní i pánevní sedimentární facie, spodnokarbonský flyš, badenské marinní a plio-pleistocenní fluviolakustrinní sedimenty (Barth et al. 1971). Zdaleka největší povrchové rozšíření v Hornomoravském úvalu mají kvartérní sedimenty.

V ose úvalu dominují fluviální sedimenty řeky Moravy a jejich přítoků, zastoupené nivními sedimenty a štěrkopísky říčních teras (Czudek 1997). Stratigraficky nejdůležitější fluviální terasou v rámci Hornomoravského úvalu je kralická terasa, která leží na starších fluviálních akumulacích (např. brodecká a lukovská terasa) nebo př́ímo na pliocenních sedimentech. Terasa je tvořena dvěma samostatnými akumulacemi štěrkopísků (Růžička 1973), z nichž ta starší je stratigraficky řazena do chladného výkyvu holštejnského interglaciálu a mladší na začátek sálského zalednění (Novák et al. 2017). V okrajových částech Hornomoravského úvalu se můžeme nejčastěji setkat se sprašemi a sprašovými hlínami. Většina je 


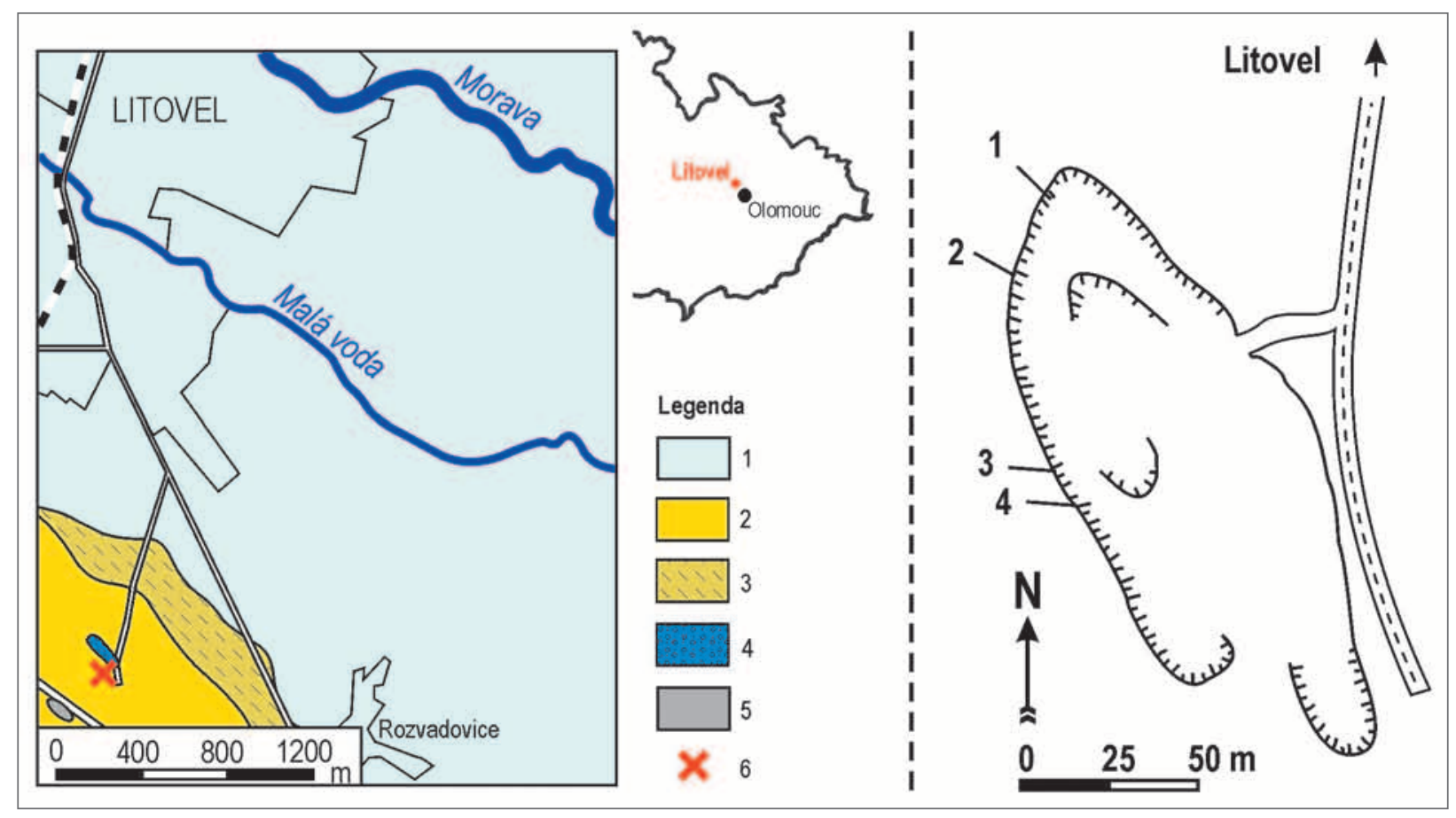

Obr. 1: Geologická mapa s polohou lokality a nákres hliníku u Litovle; 1 - nivní sedimenty (holocén); 2 - spraše a sprašové hlíny (pleistocén); 3 - hlinito-písčité až písčito-hlinité svahoviny (pleistocén); 4 - pestré fluviální a fluviolakustrinní sedimenty (pliopleistocén); 5 - břidlice, prachovce, jemnozrnné droby (drahanský kulm, rozstáňské souvrství, visé); 6 - lokalita; 1-4 - pozice dílčích zářezů (viz obr. 2).

Fig. 1: Geological map with localization of the site and sketch of brickyard in Litovel; 1 - fluvial sediments (Holocene); 2 - loess and loess loam (Pleistocene); 3 - colluvial deposits (Pleistocene); 4 - variegated fluvial and fluvio-lacustrine sediments (PliocenePleistocene); 5 - shale, siltstone, fine-grained graywacke (Drahany Culm, Rozstání Formation, Viséan); 6 - site; 1-4 - position of partial sections (see Fig. 2).

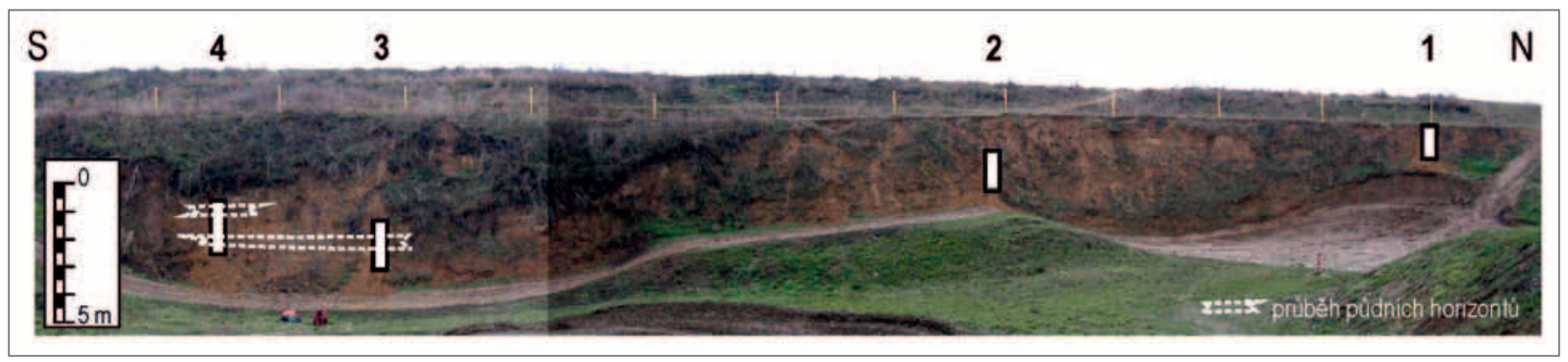

Obr. 2: Fotografie z. stěny bývalé těžebny, kde byly začištěny dílčí zářezy (1-4), ze kterých byly odebrány vzorky.

Fig. 2: Photo of western wall of the brickyard. Position of four cuts which were sampled is marked 1-4.

stratigraficky řazena do posledního viselského glaciálu. Jejich detailnější stratigrafické členění však dosud nebylo provedeno a nelze vyloučit i akumulace starší (Czudek 1997). Koluvia jsou ve formě náplavových kuželů př́ítomna při vyústění řek pramenících v Nízkém Jeseníku a na Drahanské vrchovině do Hornomoravského úvalu (Czudek 1997). Pestré spektrum kvartérních sedimentů doplňují plošně málo rozšířené chemogenní sedimenty, jako jsou travertiny a jezerní almy, poprrípadě organické sedimenty (Barth et al. 1971). Na povrchu studovaného profilu je vyvinuta holocenní luvická černozem CEl (Portál ČGS 2017).

\section{Metodika}

Na lokalitě byl po pečlivém začištění profilu proveden detailní litologický popis. Kusové vzorky, odebrané kovovou špachtlí v pravidelných $5 \mathrm{~cm}$ intervalech, byly v laboratoři Katedry geologie UP v Olomouci vysušeny při teplotě $50^{\circ} \mathrm{C}$ po dobu 24 hodin.

Tab. 1: Tabulka kalibračních rovnic a hodnot korelačních koeficientů pro vybrané prvky.

Tab. 1: Table of calibration equations and values of correlation coefficient for selected elements.

\begin{tabular}{|c|l|c|}
\hline prvek & rovnice grafu & hodnota spolehlivosti $R$ \\
\hline $\mathrm{Si}$ & $\mathrm{y}=-0,0913 \mathrm{x}^{2}+6,4012 \mathrm{x}-90,849$ & 0,91 \\
\hline $\mathrm{Al}$ & $\mathrm{y}=0,0847 \mathrm{x}^{2}-0,3165 \mathrm{x}+3,0808$ & 0,97 \\
\hline $\mathrm{Fe}$ & $\mathrm{y}=0,1235 \mathrm{x}^{2}+0,2583 \mathrm{x}+1,1443$ & 0,99 \\
\hline $\mathrm{Ca}$ & $\mathrm{y}=1,2224 \mathrm{x}-0,1187$ & 1 \\
\hline $\mathrm{K}$ & $\mathrm{y}=0,699 \mathrm{x}+0,2367$ & 0,64 \\
\hline $\mathrm{Rb}$ & $\mathrm{y}=1,1766 \mathrm{x}-11,779$ & 0,98 \\
\hline $\mathrm{Sr}$ & $\mathrm{y}=0,0031 \mathrm{x}^{2}+0,1752 \mathrm{x}+56,086$ & 0,99 \\
\hline
\end{tabular}




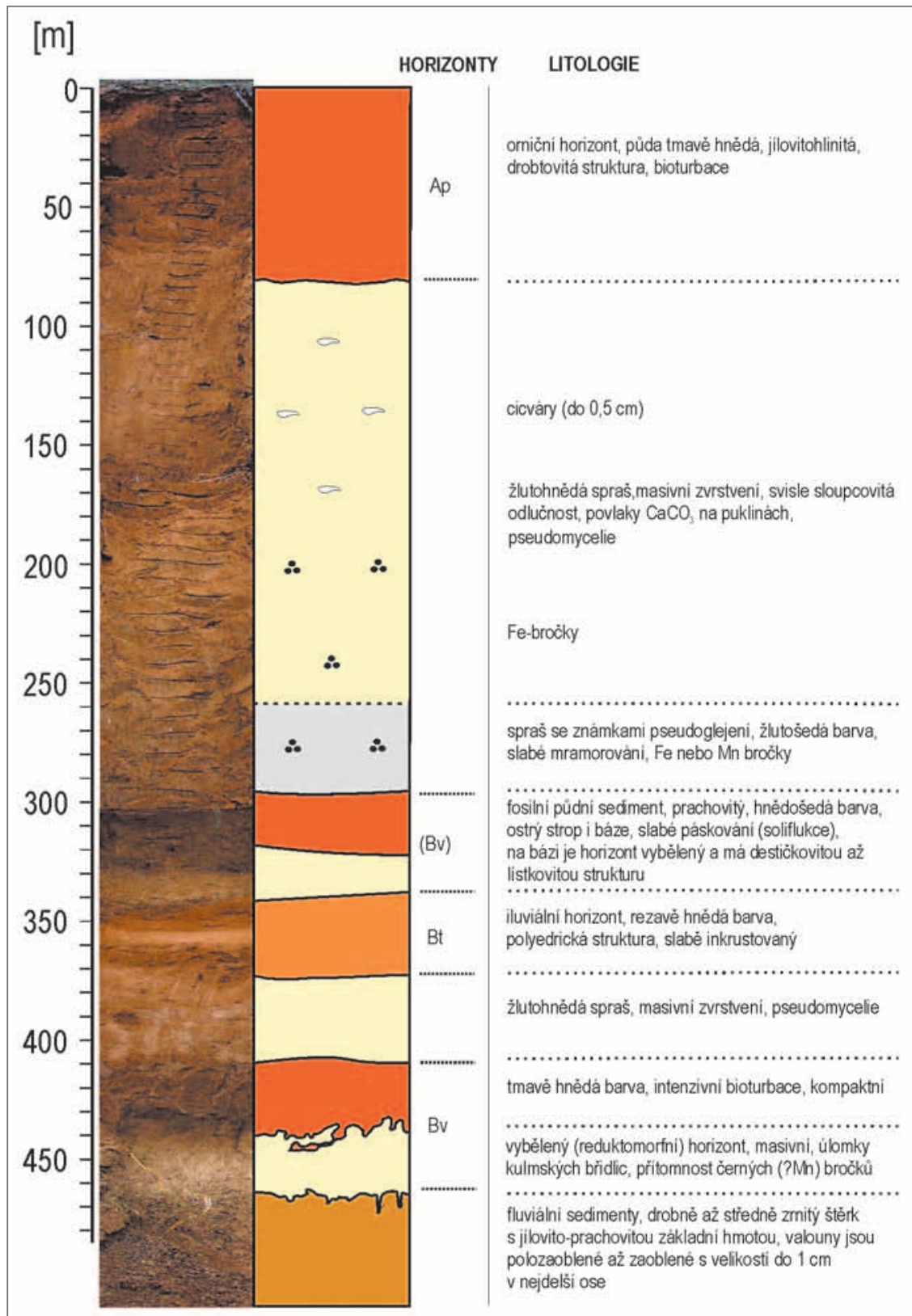

Obr. 3: Fotodokumentace složeného profilu v z. stěně hliníku a zkreslená litologie s popisem základních makroskopických znaků.

Fig. 3: Photodocumentation of integrated section at western wall of the brickyard and lithological sketch with description of basic macroscopic features.

Zrnitostní analýzy byly prováděny na laserovém granulometru Fritsch ANALYSETTE 22 NanoTec. Před měřením byl vzorek o hmotnosti $2 \mathrm{~g}$ rozmíchán $\mathrm{v} 10 \mathrm{ml}$ $10 \% \mathrm{HCl}$ kvůli odstranění karbonátů. Magnetická susceptibilita (MS) byla měřena na laboratorním kapamůstku KLY- 4 S s citlivostí $3 \times 10^{-8}$ SI. Následně byla MS přepočítána na hmotnostně specifickou magnetickou susceptibilitu (HSMS) $\left[\mathrm{m}^{3} \mathrm{~kg}^{-1}\right]$ pomocí vztahu $\chi=\mathrm{K} \times 10 / \mathrm{m} / 1000$, $\mathrm{kde}$ Kje magnetická susceptibilita [SI] a m je hmotnost vzorku [g]. Parametry barevnosti práškových vzorků byly stanoveny spektrálním fotometrem SP-62 (XRite Inc., USA), který měří spektrální odraznost ve viditelném světle $s$ krokem $10 \mathrm{~nm}$ a hodnoty kolorimetrických parametrů v barevném modelu CIE $L^{\star} a^{\star} b^{*}$. Index červenosti [\%] byl vypočten podle vztahu $\mathrm{a} / \mathrm{b} \times 100$, kde a je odraznost v červeném pásmu (635-700 nm), b je odraznost ve viditelném světle (400-700 nm). Chemické složení vzorků bylo stanoveno energiově-disperzním rentgenovým fluorescenčním (EDXRF) spektrometrem Delta Premium Innov-X. Práškové vzorky v plastových kyvetách o objemu cca $4 \mathrm{~cm}^{3}$ byly měřeny $\mathrm{v}$ modu GEOCHEM po dobu $120 \mathrm{~s}$ při urychlovacím napětí 15 a $40 \mathrm{kV}$. Metodou byly stanoveny prvky: $\mathrm{Al}, \mathrm{Si}, \mathrm{P}, \mathrm{S}, \mathrm{K}, \mathrm{Ca}, \mathrm{Ti}, \mathrm{V}, \mathrm{Mn}, \mathrm{Fe}$, $\mathrm{Ni}, \mathrm{CU}, \mathrm{Zn}, \mathrm{Rb}, \mathrm{Sr}, \mathrm{Zr}, \mathrm{Mo}, \mathrm{Pb}$. Poměry prvků fungují jako zavedená proxy-data, indikující intenzitu zvětrávání a pedogeneze (K/Al, Rb/K, Rb/Sr, Sr/Ca) nebo zrnitostní změny (Al/Si) (Ver Straeten et al. 2011; Clift et al. 2014). EDXRF data byla kalibrována na 10 vzorcích, jejichž duplikáty byly analyzovány také metodou ICP-MS (tab. 1).

\section{Litologický popis a zrnitostní analýza}

$\mathrm{Na}$ povrchu profilu byla zjištěna holocenní tmavě hnědá jílovitohlinitá půda. Od hloubky cca $80 \mathrm{~cm}$ postupně přechází do vrstvy spraší, která sahá až do hloubky 298 cm. V její svrchní části se vyskytují drobné cicváry, které od hloubky $190 \mathrm{~cm}$ mizí a začínají se objevovat několikamilimetrové tmavé bročky. Posledních cca $30 \mathrm{~cm}$ spraše nese znaky slabého pseudoglejení, projevující se mírně našedlou barvou, mramorováním a hojnými bročky. Vrstva spraší je ostře oddělena od pedokomplexu, který se skládá z několika půdních horizontů oddělených cca $30 \mathrm{~cm}$ mocnou vrstvou spraše. Svrchní a spodní půdní horizont mají shodně tmavě hnědou barvu. Pod svrchním půdním horizontem byl pozorován rezavě hnědý horizont o mocnosti cca $30 \mathrm{~cm}$. Od hloubky $465 \mathrm{~cm}$ pokračuje profil do podloží vrstvou fluviálního jemnozrnného štěrku s jílovito-prachovitou matrix. Detailní litologický popis jednotlivých částí profilu je v obrázku 3.

Střední velikost zrna ve vrstvě spraší je $25 \mu \mathrm{m}$. Obsah písčité frakce se pohybuje mezi $1,5 \mathrm{hm}$. \% a $15 \mathrm{hm}$. \% (průměrně $5,6 \mathrm{hm}$. \%) a jílová frakce je zastoupena mezi 17-25 hm. \%. Ve srovnání se sprašemi vykazují hnědé horizonty fosilní půdy mírně vyšší obsah jílové frakce a nižší obsah písčitých frakcí. Zrnitostní distribuce v holocenní 


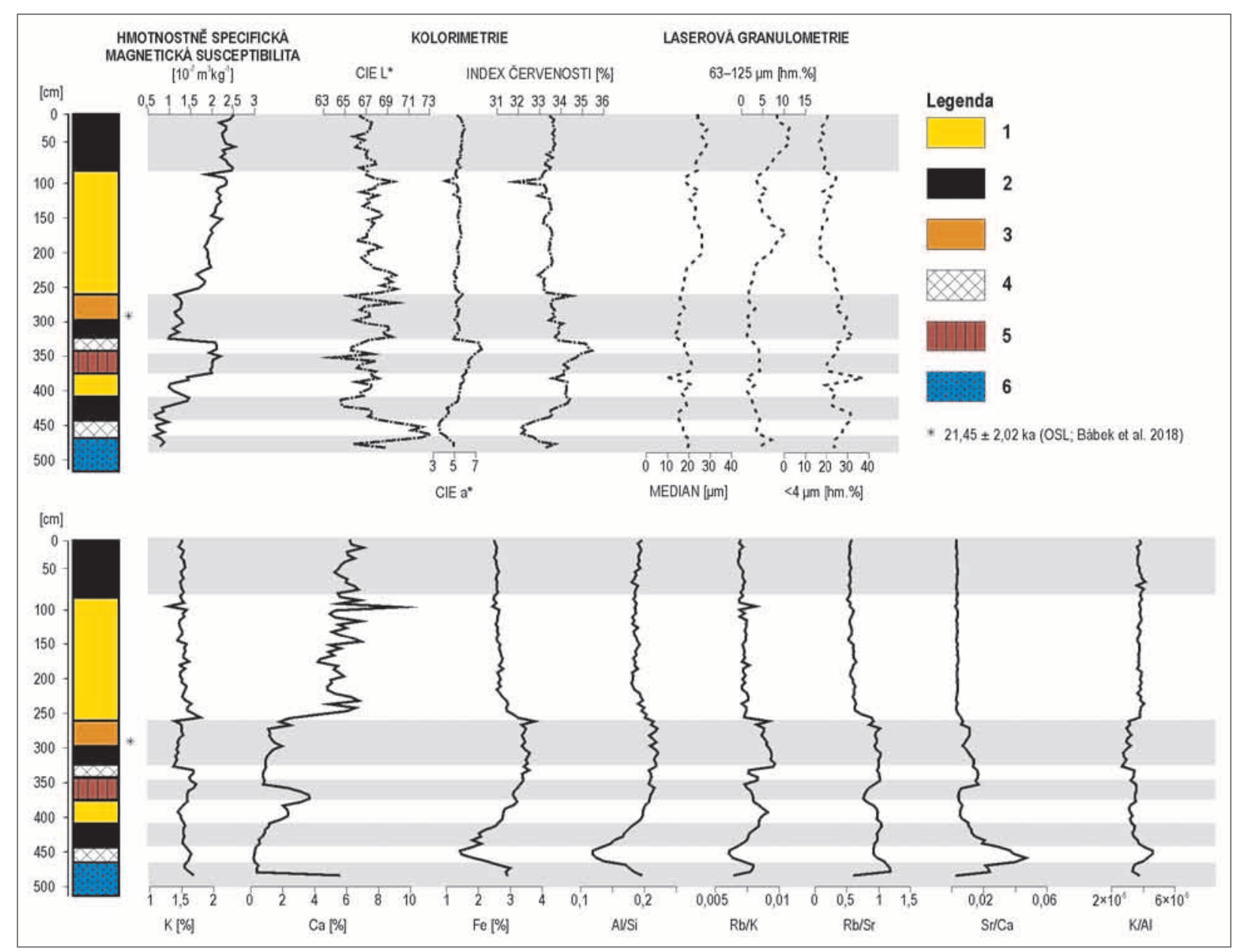

Obr. 4: Srovnání základního litologického popisu profilu Litovel s průběhem křivek HSMS, kolorimetrických, zrnitostních parametrů a vybraných geochemických proxy-dat; 1 - spraš; 2 - půda; 3 - pseudoglejový horizont; 4 - iluviální horizont; 5 - „rezavě hnědý" horizont; 6 - fluviální štěrk.

Fig. 4: Comparison of lithological sketch of Litovel section with HSMS curve, colorimetric parameters, grain size data and choosen geochemical proxy-data; 1 - loess; 2 - soil; 3 - stagnosol horizon; 4 - illuvial horizon; 5 - „rusty brown“ horizon; 6 - fluvial gravel.

půdě a rezavě hnědém horizontu fosilní půdy se neliší od spraše (obr. 4).

\section{Hmotnostně specifická magnetická susceptibilita (HSMS)}

Hodnoty HSMS se na profilu pohybují v rozsahu od $0,63 \times 10^{-7}$ do $2,55 \times 10^{-7} \mathrm{~m}^{3} \mathrm{~kg}^{-1}$. Průměrná hodnota je $1,73 \times 10^{-7} \mathrm{~m}^{3} \mathrm{~kg}^{-1}$. Holocenní půda má hodnoty v úzkém rozmezí $2,16 \times 10^{-7}-2,55 \times 10^{-7} \mathrm{~m}^{3} \mathrm{~kg}^{-1}$. Průměrná hodnota je mírně vyšší než u spraší $2,32 \times 10^{-7} \mathrm{~m}^{3} \mathrm{~kg}^{-1}$. Ve spraších lze pozorovat rozptyl hodnot od $0,63 \times 10^{-7}$ do $2,49 \times 10^{-7}$ $\mathrm{m}^{3} \mathrm{~kg}^{-1}$, s průměrem $1,82 \times 10^{-7} \mathrm{~m}^{3} \mathrm{~kg}^{-1}$. Směrem do nadloží byl ve spraši zaznamenán mírný, ale kontinuální nárůst hodnot HSMS (obr. 4). Hodnoty ve fosilních půdních horizontech se pohybují mezi $0,84 \times 10^{-7}$ až $2,21 \times 10^{-7}$ $\mathrm{m}^{3} \mathrm{~kg}^{-1}, \mathrm{~s}$ průměrem $1,49 \times 10^{-7} \mathrm{~m}^{3} \mathrm{~kg}^{-1}$. Štěrk na bázi profilu má hodnoty od $0,63 \times 10^{-7}$ do $0,85 \times 10^{-7} \mathrm{~m}^{3} \mathrm{~kg}^{-1}$. Průmèr je $0,76 \times 10^{-7} \mathrm{~m}^{3} \mathrm{~kg}^{-1}$.

\section{Difusně reflexní spektroskopie ve viditelné oblasti (DRS)}

Křivka parametru CIE $L^{*}$ (jas) je rozkolísaná (hodnoty mezi 66 až 69), ale výraznější výkyv (73), korelovatelný s litologickou změnou je pouze na hranici půdního komplexu a podložních štěrků (obr. 4). Hodnoty parametru CIE a* (červeno-zelená osa) se na profilu pohybují mezi 3 až 7 . V holocenní půdě, vrstvě spraší i svrchní části fosilního pedokomplexu je křivka téměř uniformní. Výraznější výkyv lze zhruba korelovat s přítomností rezavě hnědého horizontu (obr. 3). Poté se hodnoty parametru do podloží postupně snižují. Hodnoty indexu červenosti poměrně dobře kopírují křivku parametru CIE $\mathrm{a}^{*}$, křivka je pouze více „zubatá“.

\section{Geochemická charakteristika}

Průměrný obsah $\mathrm{K}$ ve studovaném profilu je 1,6\%. Litologické změny průběh křivky $K$ téměř neovlivňují (obr. 4). Mírný pokles hodnot lze pozorovat v horizontu pseudoglejené spraše a svrchního půdního horizontu fosilního pedokomplexu. Koncentrace Ca ve spraších se pohybují v rozpětí 4,5-6,0\%. Ve fosilním pedokomplexu nepřesahují koncentrace Ca $1 \%$. Naopak, koncentrace Fe jsou ve spraších poměrně nízké (průměrně $2,4 \%$ ), ale ve svrchní části fosilního pedokomplexu narůstají na téměř $4 \%$. Postupně obsah Fe do podloží opět klesá a na hranici pedokomplexu a štěrku dosahuje svého 
minima (1,3\%). Křivka poměru Fe téměř dokonale kopíruje křivku poměru $\mathrm{Al} / \mathrm{Si}$. Hodnoty poměru se pohybují mezi 0,12 až 0,23 a spraše se vyznačují nižšími hodnotami než fosilní pedokomplex. Hodnoty poměru $\mathrm{Rb} / \mathrm{K} \mathrm{a} \mathrm{Rb} /$ Sr spolu dobře korelují a u obou pozorujeme ve fosilním pedokomplexu obecně vyšší hodnoty než ve spraších. Zvýšení hodnot obou poměrů lze korelovat s rozhraním spraš a pseudoglejená spraš. Snížení v rámci pedokomplexu odpovídá přítomnosti rezavě hnědého horizontu a v případě křivky $\mathrm{Rb} / \mathrm{K}$ také hranice pedokomplex/štěrk. Podobně i v případě poměru Sr/Ca se hodnoty zvyšují na hranici spraš/pseudoglejená spraš. Nejvyšší hodnoty poměru byly zjištěny na rozhraní fosilní pedokomplex/ štěrk. Křivka poměru K/Al je poměrně uniformní, k mírnému snížení hodnot dochází v pseudoglejeném horizontu spraše a svrchní části fosilního pedokomplexu.

\section{Diskuze}

Na povrchu studovaného profilu je vyvinuta holocenní půda. Výsledky korespondují s přítomností luvické černozemě (CEl), pro kterou je typický dobře vyvinutý humusový orniční horizont Ap (Šarapatka 2014), zvýšené hodnoty HSMS a nízké hodnoty CIE L* (cf. Veselská 2015). Geochemicky se holocenní půda neliší od podložní spraše, což bylo pozorováno i na jiných českých a moravských lokalitách (Hošek et al. 2015).

Litologický charakter spraše v Litovli, hodnoty kolorimetrických parametrů i koncentrace Ca odpovídají typické vápnité spraši (Petránek 1963; Lisá 2004; Bábek et al. 2011; Lisá et al. 2014). Makrofosilie nebyly pozorovány na výchozu ani v rozplavených laboratorních vzorcích. Avšak, na základě téměř totožných hodnot HSMS, kolorimetrických parametrů i geochemických proxy-dat lze tento horizont korelovat se 17 km vzdáleným sprašovým profilem Hlásnice u Šternberka, kde se hojně vyskytují plži rodu Pupilla a Succinella (Krulová 2016). Ložek (2001) na základě jejich výskytu interpretuje klima jako chladné tundrové, avšak relativně humidní s výskytem křovinaté stepi. Na bázi sprašového pokryvu lze pozorovat makroskopické známky pseudoglejení. Vyznačuje se mírně našedlou barvou, nízkými hodnotami HSMS (Evans, Heller 2001), K/Al a nízkými koncentracemi Ca a vyššími hodnotami koncentrací $\mathrm{Fe}$ a vyššími poměry $\mathrm{Al} / \mathrm{Si}$ a Rb/K (obr. 4). Pseudoglejení mohlo být způsobeno stagnací srážkové vody na méně propustném (jílovou frakcí nabohaceném) illimerizovaném podložním pedokomplexu (Tomášek 1995; Šarapatka 2014). Fosilní pedokomplex je tvořen několika horizonty. Ve svrchní části se vyskytuje hnědě zbarvený horizont, který byl interpretován jako půdní sediment, vzhledem k ostrému ohraničení vůči okolním vrstvám, nepřítomnosti bioturbace a slabé soliflukci (Antoine et al. 2013). Spodní hnědě zbarvený horizont je nejspíše autochtonní, protože geneticky vychází ze svého podloží. Podle zvýšeného obsahu jílu a nízkého obsahu Ca lze usuzovat na Bv horizonty luvické (cf. Šaraptka 2014). Spodní část půdního sedimentu je silně vybělená, což ukazuje na vyloužení Fe a dalších prvků, které se pak hromadí v níže položeném rezavě hnědém horizontu. Podle barvy, nízkého obsahu jílu, slabé inkrustace a kompaktní struktury lze tento horizont interpretovat jako iluviální horizont Bt (Šarapatka 2014). Přítomnost těchto dvou horizontů je typická pro hnědozem (sensu Tomášek 1995). Illimerizační proces se $\mathrm{v}$ případě Litovle neprojevuje makroskopicky nijak výrazně, což je pro půdní typ hnědozem typické (Šarapatka 2014). Fosilní půdní komplex v Litovli by mohl stratigraficky odpovídat PK I na jiných moravských lokalitách. Hlavním argumentem je OSL datování báze svrchního sprašového pokryvu v Litovli do doby cca 21500 let BP (Bábek et al. 2018). V Dolních Věstonicích byla svrchní část PK I datována radiokarbonově na 26 000-29 000 let $\mathrm{BP}$, což odpovídá teplotně průměrnému interstadiálu denekamp (Frechen et al. 1999). Stejně jako v Litovli je PK I na většině tuzemských lokalit interpretována jako slabě vyvinutá illimerizovaná hnědozem (cf. Antoine et al. 2013; Hošek et al. 2015). Kolorimetrické parametry ve fosilní půdě v Litovli odpovídají hodnotám, které byly naměřeny v PK I v Dolních Věstonicích. Starší pedokomplexy se vyznačují výrazně nižšími hodnotami CIEL (Bábek et al. 2011). Zrnitostně se fosilní půda v Litovli podobá PK I v Zeměměších, Dobšicích (Hošek et al. 2015) i Dolních Věstonicích (Antoine et al. 2013), kde se obsah jílu pohybuje mezi 20 až $30 \%$ a obsah velmi jemnozrnné písčité frakce klesá blízko $0 \%$. Na stejných lokalitách je poměr Rb/Sr v PK I jen mírně vyšší než ve spraši a pohybuje se okolo 1 (Hošek et al. 2015), což odpovídá zjištěním v Litovli. Nízké obsahy Ca ve fosilní půdě v Litovli odpovídají dekalcifikaci slabě vyvinutých interstadiálních půd (Smolíková 1984). PK I se na většině tuzemských lokalit vyznačuje jen mírnou pozitivní (některé části PK I dokonce žádnou) odezvou v křivkách magnetické susceptibility, na rozdíl od starších pedokomplexů s výraznými pozitivními výchylkami (Antoine et al. 2013; Hošek et al. 2015). Hodnoty HSMS ve fosilním pedokomplexu v Litovli jsou srovnatelné (rezavě hnědý horizont I) nebo dokonce nižší (fosilní půdní sediment i půdní horizont Bt) než v nadložním sprašovém pokryvu. Tento jev by bylo možné vysvětlit kombinací několika faktorů. Působení chladného boreálního až arktického klimatu (cf. Smolíková 1990) způsobilo zpomalení pedogenetických změn a nižší obsahy oxi/hydroxidů Fe v PK I v Litovli. Současně, relativně humidní klima, mohlo dále přispět k vyloužení těchto minerálů $\mathrm{Fe} \mathrm{z}$ půdních horizontů. Hlavní výkyvy v křivce HSMS ve fosilním pedokomplexu $(300-400 \mathrm{~cm})$ jsou pravděpodobně způsobeny intenzitou destrukce oxi/ hydroxidů $\mathrm{Fe}$, vyloužením železa a jeho následné krystalizace $\mathrm{v}$ podobě jiných minerálů (sulfidy, křemičitany, fosfáty, atd.) v souvislosti s pedogenetickými procesy. Zatímco magnetická susceptibilita kolísá v souvislosti s potenciálním minerálním nosičem Fe v jednotlivých horizontech, samotná koncentrace tohoto prvku v profilu je zřejmě ovlivněna zrnitostí, jak ukazuje podobný vývoj křivek Fe a Al/Si (Sterckeman et al. 2006). Pro přesnější stanovení pedogenních procesů a přesnější paleoklimatologické interpretace by bylo nezbytné provést detailní mikromorfologický a mineralogický výzkum, případně použít další petrofyzikální metody, např. frekvenčně závislé magnetické susceptibility. 
Závěr

Na lokalitě u Litovle byl studován sprašo-půdní komplex ze závěru posledního zalednění. Pod typicky vyvinutou spraší se nachází půdní vrstvy, interpretované na základě petrofyzikálních a geochemických dat jako PK I. Půda pravděpodobně vznikla v chladných, ale relativně humidních interstadiálních podmínkách. Usuzujeme na to z nízkého magnetického signálu, který je ve fosilní půdě dokonce nižší než ve spraši. To neodpovídá běžnému chování magnetické susceptibility ve sprašo-půdních komplexech v České republice. Možným vysvětlením je snížená produkce oxi/hydroxidů Fe (hlavní nositelé MS signálu) v chladném klimatu, doplněná navíc jejich destrukcí během illimerizačního procesu.

\section{Poděkování}

Tento článekvzniklzapodporyprojektuIGA_PrF_2017_022. Chtěli bychom také poděkovat dvěma anonymním recenzentưm za jejich věcné pripomínky.

\section{Literatura}

Antoine, P., Rousseau, D. D., Degeai, J. P., Moine, O., Lagroix, F., Kreutzer, S., Fuchs, M., Hatté, Ch., Gauthier, C., Svoboda, J., Lisá, L. (2013). High-resolution record of the environmental response to climatic variations during the Last InterglacialGlacial cycle in Central Europe: the loess-palaeosol sequence of Dolní Věstonice (Czech Republic). - Quaternary Science Reviews, 67, 17-38. https://doi.org/10.1016/j.quascirev.2013.01.014.

Bábek, O., Chlachula, J., Matys Grygar, T. (2011). Non-magnetic indicators of pedogenesis related to loess magnetic enhancement and depletion: Examples from the Czech Republic and southern Siberia. - Quaternary Science Reviews, 30, 967-979. https://doi.org/10.1016/j.quascirev.2011.01.009.

Bábek, O., Sedláček, J., Novák, A., Létal, A. (2018). Electrical resistivity imaging of anastomosing river subsurface stratigraphy and possible controls of fluvial style change in a graben-like basin, Czech Republic. - Geomorphology, 317, 139-156. https:// doi.org/10.1016/j.geomorph.2018.05.012.

Barth, V., Kopečný, V., Panoš, V., Pek, I., Zapletal, J. (1971). Geologické exkurze do Hornomoravského úvalu a okolí. - 96 s. Př́írodovědecká fakulta Univerzity Palackého. Olomouc.

Cílek, V. (2001). The loess deposits of the Bohemian Massif: silt provenance, paleometeorology and loessification processes. Quaternary International, 76/77, 123-128. https://doi.org/10.1016/S1040-6182(00)00096-3.

Clift, P. D., Wan, S., Blusztajn, J. (2014). Reconstructing chemical weathering, physical erosion and monsoon intensity since 25 $\mathrm{Ma}$ in the northern South China Sea: A review of competing proxies. - Earth-Science Reviews, 130, 86-102. https://doi. org/10.1016/j.earscirev.2014.01.002.

Czudek, T. (1997). Reliéf Moravy a Slezska v kvartéru. - 213. Sursum. Tišnov.

Demek, J., Mackovčin, P., Balatka, B., Buček, A., Cibulková, P., Culek, M., Čermák, P., Slavík, P., Vašátko, J. (2006). Hory a nížiny. Zeměpisný lexikon ČR. - 582 s. AOPAK ČR. Brno.

Evans, M. E., Heller, F. (2001). Magnetism of loess/palaeosol sequences: recent developments. - Earth-Science Reviews, 54, $129-144$. https://doi.org/10.1016/S0012-8252(01)00044-7.

Frechen, M., Zander, A., Cílek, V., Ložek, V. (1999). Loess chronology of the Last Interglacial/Glacial cycle in Bohemia and Moravia, Czech Republic. - Quaternary Science Reviews, 18, 1467-1493. https://doi.org/10.1016/S0277-3791(98)00087-0.

Hošek, J., Hambach, U., Lisá, L., Matys Grygar, T., Horáček, I., Meszner, S., Knésl, I. (2015). An integrated rock-magnetic and geochemical approach to loess/paleosol sequences from Bohemia and Moravia (Czech Republic): Implications for the Upper Plesitocene paleoenvironment in Central Europe. - Palaeogeography, Palaeoclimatology, Palaeoecology, 418, 344-358. https://doi.org/10.1016/j.palaeo.2014.11.024.

Krulová, V. (2016). Petrofyzikální studium sprašových profilů v Hornomoravském úvalu. - MS, bakalářská práce, Přírodovědecká fakulta Univerzity Palackého. Olomouc.

Kukla, G., Cílek, V. (1996). Plio-pleistocene megacycles: record of climate and tectonics. - Palaeogeography, Palaeoclimatology, Palaeoecology, 120, 1/2, 171-194. https://doi.org/10.1016/0031-0182(95)00040-2.

Lisá, L. (2004). Exoscopy of Moravian eolian sediments. - Bulletin of Geosciences, 79, 3, 177-182.

Lisá, L., Hošek, J., Bajer, A., Matys Grygar, T., Vandenberghe, D. (2014). Geoarchaeology of Upper Palaeolithic loess sites located within a transect through Moravian valleys, Czech Republic. - Quaternary International, 351, 25-37. https://doi. org/10.1016/j.quaint.2013.08.058.

Ložek, V. (2001). Molluscan fauna from the loess series of Bohemia and Moravia. - Quaternary International, 76/77, 141-156. https://doi.org/10.1016/S1040-6182(00)00098-7.

Novák, A., Bábek, O., Kapusta, J. (2017). Late Quaternary tectonic switching of siliciclastic provenance in the strike-slip-dominated foreland of the Western Carpathians; Upper Morava Basin, Bohemian Massif. - Sedimentary Geology, 355, 58-74. https://doi.org/10.1016/j.sedgeo.2017.04.005.

Petránek, J. (1963). Usazené horniny. - 718 s. Nakladatelství Československé akademie věd. Praha.

Portál ČGS (2017). Půdní mapa, list 24-22 Olomouc. - Dostupné na: http://mapy.geology.cz/pudy/, 27. 10. 2017.

Pye, K. (1995). The nature, origin and accumulation of loess. - Quaternary Science Reviews, 14, 653-667. https://doi.org/10.1016/0277-3791(95)00047-X.

Růžička, M. (1973). Fluviální sedimenty řeky Moravy v okolí Olomouce. - Sborník geologických věd, Antropozoikum, A/9, 7-43. Smalley, I. J., Vita-Finzi, C. (1968). The formation of fine particles in sandy deserts and the nature of 'desert' loess. - Journal of Sedimentary Petrology, 38, 766-774. 
Smith, B. J., Wright, J. S., Whalley, W. B. (2002). Sources of non-glacial, loess-size quartz silt and the origins of “desert loess". Earth-Science Reviews, 59, 1-26. https://doi.org/10.1016/S0012-8252(02)00066-1.

Smolíková, L. (1984). On the Development of Pleistocene Soils in Czechoslovakia. - In: Pécsi, M. (ed.): Lithology and Stratigraphy of Loess and Paleosols, 33-38, Geographical Research Institute, Hungarian Academy of Sciences. Budapest.

Smolíková, L. (1990). Problematika paleopedologie, Regionální paleopedologie, Zákonitosti půdního vývoje v kvartéru. - In: Smolíková, L., Kutílek, M., Němeček, J. (eds.): Pedologie a paleopedologie, 430-442, Academia. Praha.

Sterckeman, T., Douay F., Baize, D., Fourrier, H., Proix, N., Schvartz, C., Carigan, J. (2006). Trace element distributions in soil developed in loess deposits from northern France. - European Journal of Soil Science, 57, 392-410. https://doi.org/10.1111/j.1365-2389.2005.00750.x.

Šarapatka, B. (2014). Pedologie a ochrana půdy. - 232 s. Univerzita Palackého v Olomouci. Olomouc.

Tomášek, M. (1995). Atlas půd České republiky. - 36 s. Český geologický ústav. Praha.

Ver Straeten, Ch. A., Brett, C. B., Sageman, B. B. (2011). Mudrock sequence stratigraphy: A multi-proxy (sedimentological, paleobiological and geochemical) approach, Devonian Appalachian Basin. - Palaeogeography, Palaeoclimatology, Palaeocology, $304,57-73$.

Veselská, V. (2015). Barevné modely a použití kolorimetrických parametrů v půdních profilech. - MS, bakalářská práce, Přírodovědecká fakulta Univerzity Palackého. Olomouc.

Zeman, A., Demek, J. (1984). Kvartér: geologie a geomorfologie. - 192 s. Státní pedagogické nakladatelství. Praha. 